\title{
Review \\ Dysferlin and Animal Models for Dysferlinopathy
}

\author{
Kinji Kobayashi1,2, Takeshi Izawa1, Mitsuru Kuwamura1, and Jyoji Yamate1 \\ ${ }^{1}$ Laboratory of Veterinary Pathology, Division of Veterinary Sciences, Graduate School of Life and Environmental Sciences, Osaka \\ Prefecture University, 1-58 Rinku-ourai-kita, Izumisano City, Osaka 598-8531, Japan \\ 2 Pathological Department, Osaka Pathological Center, Drug Safety Research Laboratories, Contract Research Company, Shin \\ Nippon Biomedical Laboratories, Ltd., Sumitomo Mitsui Banking Corporation Korai-bashi Building, 8F, 2-1-1 Fushimi-machi, \\ Chuo-ku, Osaka 541-0044, Japan
}

\begin{abstract}
Dysferlin (DYSF) is involved in the membrane-repair process, in the intracellular vesicle system and in T-tubule development in skeletal muscle. It interacts with mitsugumin 53, annexins, caveolin-3, AHNAK, affixin, S100A10, calpain-3, tubulin and dihydropyridine receptor. Limb-girdle muscular dystrophy 2B (LGMD2B) and Miyoshi myopathy (MM) are muscular dystrophies associated with recessively inherited mutations in the DYSF gene. The diseases are characterized by weakness and muscle atrophy that progress slowly and symmetrically in the proximal muscles of the limb girdles. LGMD2B and MM, which are collectively termed "dysferlinopathy", both lead to abnormalities in vesicle traffic and membrane repair at the plasma membrane in muscle fibers. SJL/J (SJL) and A/J mice are naturally occurring animal models for dysferlinopathy. Since there has been no an approach to therapy for dysferlinopathy, the immediate development of a therapeutic method for this genetic disorder is desirable. The murine models are useful in verification experiments for new therapies and they are valuable tools for identifying factors that accelerate dystrophic changes in skeletal muscle. It could be possible that the genetic or immunological background in SJL or A/J mice could modify muscle damage in experiments involving these models, because $\mathrm{SJL}$ and $\mathrm{A} / \mathrm{J}$ mice show differences in the progress and prevalent sites of skeletal muscle lesions as well as in the gene-expression profiles of their skeletal muscle. In this review, we provide up-to-date information on the function of dysferlin, the development of possible therapies for muscle dystrophies (including dysferlinopathy) and the detection of new therapeutic targets for dysferlinopathy by means of experiments using animal models for dysferlinopathy. (DOI: 10.1293/tox.25.135; J Toxicol Pathol 2012; 25: 135-147)
\end{abstract}

Key words : SJL/J mouse, A/J mouse, dysferlin, complement, dysferlinopathy

\section{Introduction}

Muscular dystrophy is a generic term that is used to refer to a group of hereditary muscular disorders characterized clinically by progressive muscular weakness and muscle atrophy and histopathologically by degeneration/necrosis and regeneration of skeletal muscle fibers. This group of inherited muscular disorders includes Duchenne muscular dystrophy (DMD), Becker muscular dystrophy (BMD), Emery-Dreifuss muscular dystrophy, limb-girdle muscular dystrophy (LGMD), distal muscular dystrophy including

Received: 28 February 2012, Accepted: 16 March 2012 Mailing address: Kinji Kobayashi, Pathological Department, Osaka Pathological Center, Drug Safety Research Laboratories, Contract Research Company, Shin Nippon Biomedical Laboratories, Ltd., Sumitomo Mitsui Banking Corporation Korai-bashi Building, 8F, 2-1-1 Fushimi-machi, Chuo-ku, Osaka 541-0044, Japan

TEL: 81-6-6233-8432 FAX: 81-6-6233-8433

E-mail: kobayashi-kinji@snbl.co.jp

(C)2012 The Japanese Society of Toxicologic Pathology

This is an open-access article distributed under the terms of the Creative Commons Attribution Non-Commercial No Derivatives (by-ncnd) License $<$ http://creativecommons.org/licenses/by-nc-nd/3.0/> .
Miyoshi myopathy (MM) and Fukuyama/non-Fukuyama congenital muscular dystrophy among others ${ }^{1}$. Of these disorders, LGMD is a muscular disorder in which weakness and atrophy of muscles progress slowly and symmetrically in the proximal muscles of the limb girdle. Because LGMD includes many types of unclassified muscular dystrophy and is etiologically heterogeneous, a locus-based classification has been proposed by a consortium that met under the auspices of the European Neuromuscular Centre. In this classification, the dominant LGMD loci are designated LGMD1A, LGMD1B, LGMD1C, etc., and the recessive loci are designated as LGMD2A, LGMD2B, LGMD2C, etc., in the order that they were identified ${ }^{2}$.

LGMD2B and MM are both caused by recessively inherited mutations in the dysferlin (DYSF) genel. LGMD2B is characterized by progressive wasting and weakness of the muscles of the proximal lower limb girdle, whereas MM mostly affects the distal muscle groups of the limb girdle. Both disorders are considered to result from a loss of dysferlin (DYSF) protein from the plasma membrane of muscle fibers, leading to abnormalities in vesicle traffic and membrane repair ${ }^{3,4}$; this process is collectively referred to as "dysferlinopathy". 
The prevalence of progressive muscular dystrophy among the general population is about four cases in 100,000 people ${ }^{5}$. The relative frequency by the type of disease is $60 \%$ DMD, 30\% LGMD and 10\% facioscapulohumeral dystrophy. Among the 1420 patients diagnosed with muscular dystrophies at the National Center of Neurology and Psychiatry (Japan) in 2004, dystrophinopathy (DMD/BMD) $(56 \%)$ was the most common condition followed by LGMD (19\%). Of these LGMD patients, $18 \%$ were diagnosed with LGMD2B, which occurs at a relatively higher frequency in Japan than elsewhere ${ }^{6}$. At the same facility in 2010, dysferlinopathy was identified as the most frequent type of LGMD present among the Japanese population?

The progression of muscular dystrophy confines patients to a wheelchair or a ventilator, and it detracts from their quality of life. Various approaches to definitive therapy of muscular dystrophy have been attempted. These include gene therapies, such as gene transfer using plasmids or adeno-associated virus (AAV) vectors, or exon skipping using antisense oligonucleotides (AVI-4658 or GSK-2402968 $[\mathrm{PRO}-051])^{8-10}$; cell-based therapies ${ }^{11}$; therapies using small-molecule drugs that act through a read-through mechanism, such as aminoglycosides ${ }^{12-14}$, ataluren (PTC124) ${ }^{15}$ or TG00316; and an antibody therapy using anti-myostatin antibody17. Clinical studies for some of these therapies are ongoing in DMD/BMD patients or others. Since there has been no an approach to therapy for dysferlinopathy, the immediate development of a therapeutic method for this genetic disorder is desirable.

As described above, although dysferlinopathy is a type of muscular dystrophy that has a relatively high prevalence in Japan, the development of a standard therapy has been slow, and therefore, animal models of dysferlinopathy remain useful for verification experiments on novel therapies. Additionally, because the histopathological lesions are localized in the limb-girdle muscles, despite a systemic deficiency in dysferlin protein, accelerating factors that produce the muscular damage in only the limb-girdle muscles must be present in patients with dysferlinopathy, and animal models of dysferlinopathy are useful as tools for exploring these accelerating factors.

This review provides up-to-date information on the function of dysferlin, the development of possible therapies for muscle dystrophies (including dysferlinopathy) and the detection of new therapeutic targets for dysferlinopathy by means of experiments using animal models for dysferlinopathy. It also discusses the effectiveness and the problems of using animal models for dysferlinopathy.

\section{The Function of Dysferlin}

\section{The role of dysferlin in membrane-repair processes} and in the intracellular vesicular system

DYSF is a $230-\mathrm{kDa}$ transmembrane protein that has a C-terminal transmembrane domain. The DYSF gene is abundantly expressed in skeletal and cardiac muscle ${ }^{18}$, and its gene product is distinct from the dystrophin-glycopro- tein complex (Fig. 1) ${ }^{19}$. DYSF belongs to the ferlin family, which includes otoferlin, myoferlin and Fer-1 (identified in Caenorhabditis elegans ${ }^{4}$ ). The proteins of the ferlin family have several calcium-binding $\mathrm{C} 2$ domains associated with calcium-dependent membrane fusion and repair ${ }^{4}$ (Fig. 2). Fer-1 mediates calcium-dependent membrane fusion of multiple intracellular vesicles (called "membranous organellas") to the spermatid plasma membrane during spermatogenesis in C. elegans ${ }^{4}$. DYSF has seven C2 domains and is implicated in Ca-dependent resealing after disruption of the sarcolemma. It is known that the membrane-repair process requires intracellular vesicles ${ }^{20}$ that deliver excess membrane to form a "membrane patch" through calciumtriggered vesicular exocytosis ${ }^{21,22}$. It has been suggested that these intracellular vesicles are initially transported to the site of damage by sequential actions of motor proteins, including kinesin and nonmuscle myosin IIA and IIB ${ }^{23,24}$. It has also been suggested that DYSF is distributed to these intracellular vesicles together with caveolin-325, and it has been reported that DYSF is also associated with annexins $\mathrm{A} 1$ and $\mathrm{A} 2$ in a $\mathrm{Ca}^{2+}$ - and membrane injury-dependent manner ${ }^{26}$.

Some studies have suggested that mitsugumin 53 (MG53) plays a role in facilitated vesicle translocation for muscle membrane repair ${ }^{27-32}$. The interactions between DYSF, MG53 and caveolin-3 have been examined in vitro by means of immunoprecipitation experiments ${ }^{27}$. Accordingly, DYSF is considered to act with MG53, annexins and other proteins in the accumulation of vesicles at the site of damage following membrane disruption (Fig. 3). In addition to MG53, annexins and caveolin-3, human neuroblast differentiation-associated protein (AHNAK) ${ }^{33}$, affixin ${ }^{34}$, S100A10 ${ }^{35}$, calpain-336, tubulin ${ }^{37}$, and dihydropyridine receptor (DHPR) ${ }^{38}$ have been reported to interact with DYSF. Figure 4 shows a schema of the proteins that interact with DYSF at the sarcolemma in skeletal muscle.

\section{The role of dysferlin in T-tubule development}

Some recent studies have shown that DYSF is active in with the development of T-tubules ${ }^{39,40}$. DYSF has been observed to be associated with developing T-tubules and also to interact with DHPR at the sarcolemma of T-tubules ${ }^{40}$. Because a deficiency in DYSF induces ultrastructural abnormalities in primary T-tubules in skeletal muscle, it has been suggested that DYSF is required for the maintenance or development of T-tubules.

\section{The role of dysferlin in ATP release and intracellular $\mathrm{Ca}^{2+}$ signaling}

Another study has indicated that DYSF might be involved in ATP release and intercellular $\mathrm{Ca}^{2+}$ signaling ${ }^{41}$. It has been suggested that DYSF mediates $\mathrm{Ca}^{2+}$-triggered intercellular signaling in response to membrane wounding in sea urchin embryos, as it has been shown that morpholino knockdown of DYSF mRNA expression in sea urchin embryos effectively blocks the release of ATP after membrane damage and thereby suppresses the consequent intercellular 


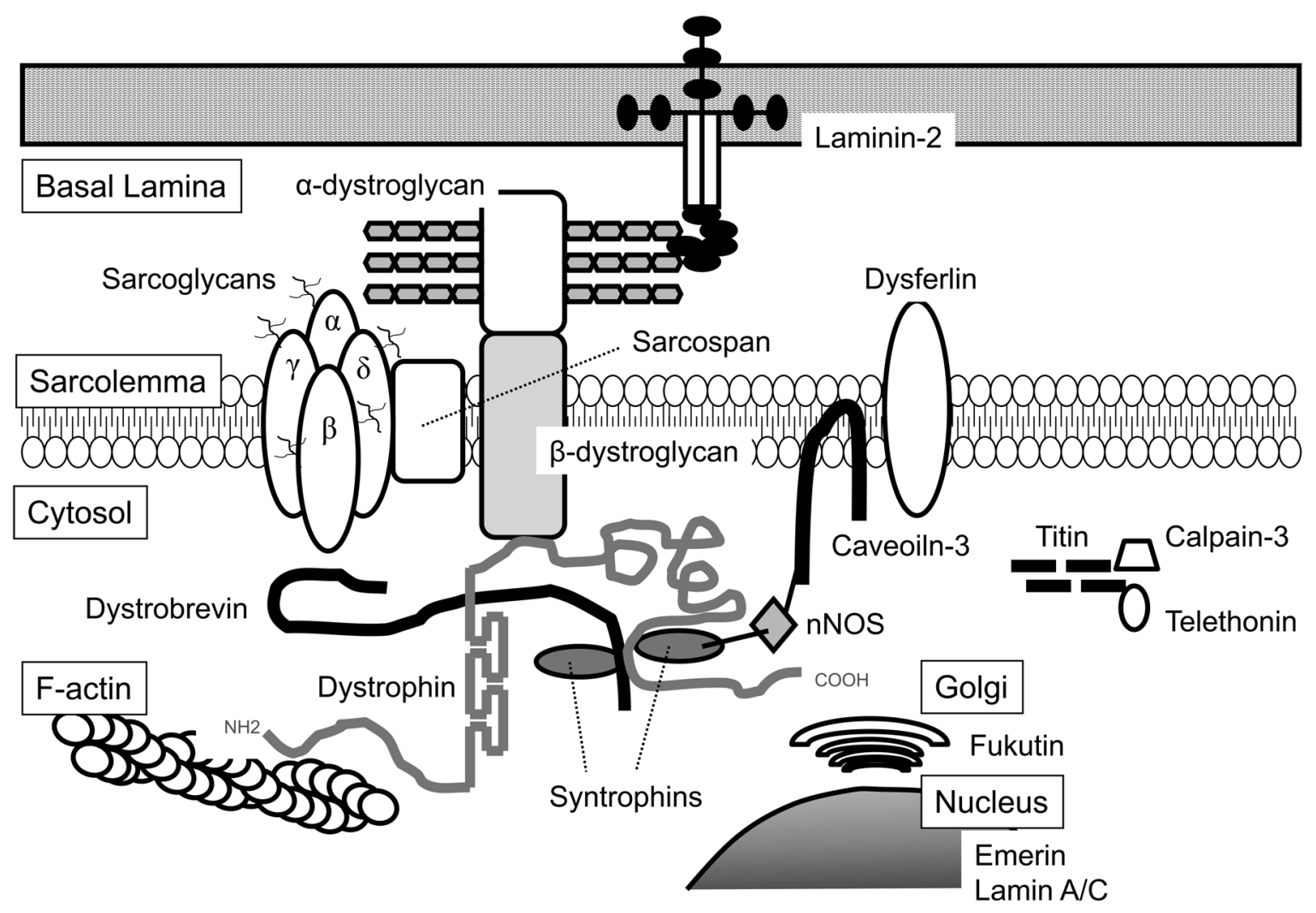

Fig. 1. Schematic showing the organization of some of the integral and peripheral components involved in muscular dystrophies in skeletal muscles.
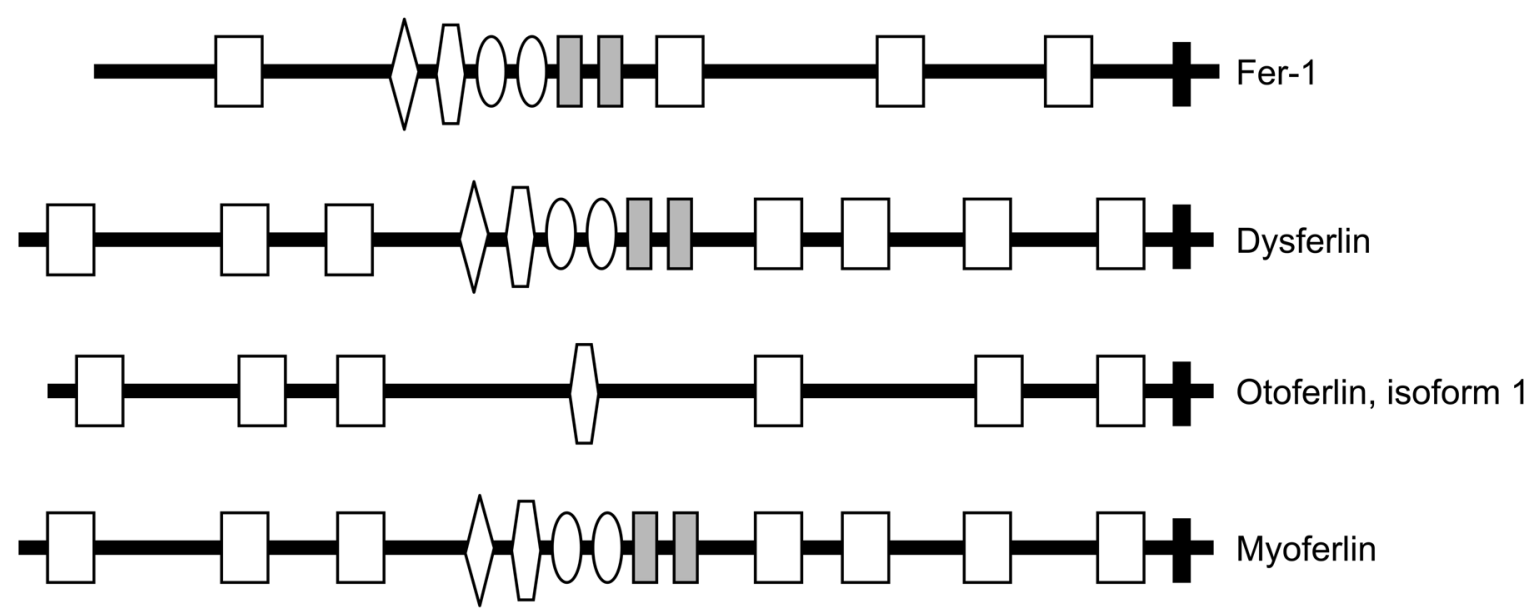

$\square$ C2 domain (calcium-binding domain)

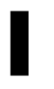

C-terminal transmembrane domain

$\oint$ DysfN (unknown function) $\bigwedge$

FerA (unknown function)

$\coprod$

FerB (unknown function)

DysfC (unknown function)

Fig. 2. Conserved structure of the ferlin family. Proteins of the ferlin family have highly homologous structures. The proteins have a variable number of tandem $\mathrm{C} 2$ domains and a C-terminal transmembrane domain. 


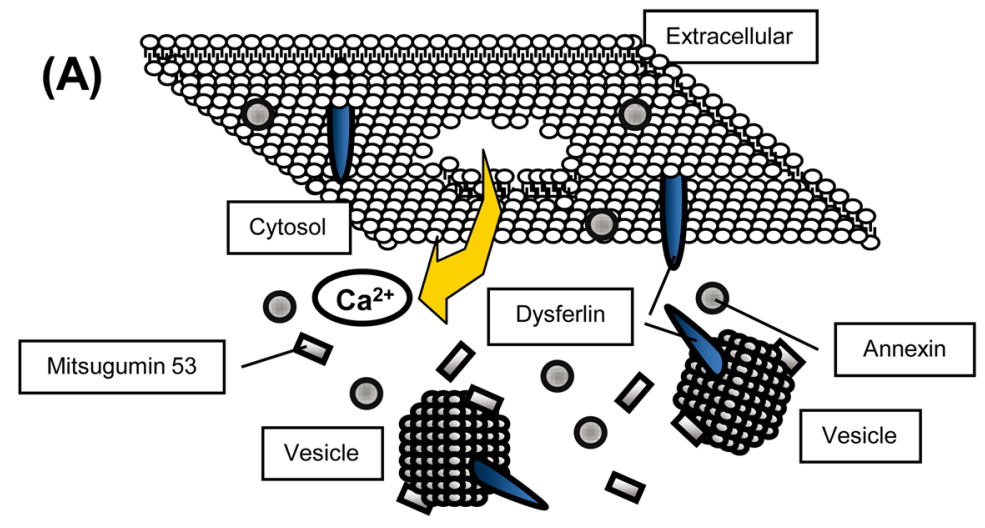

(C)

(B)
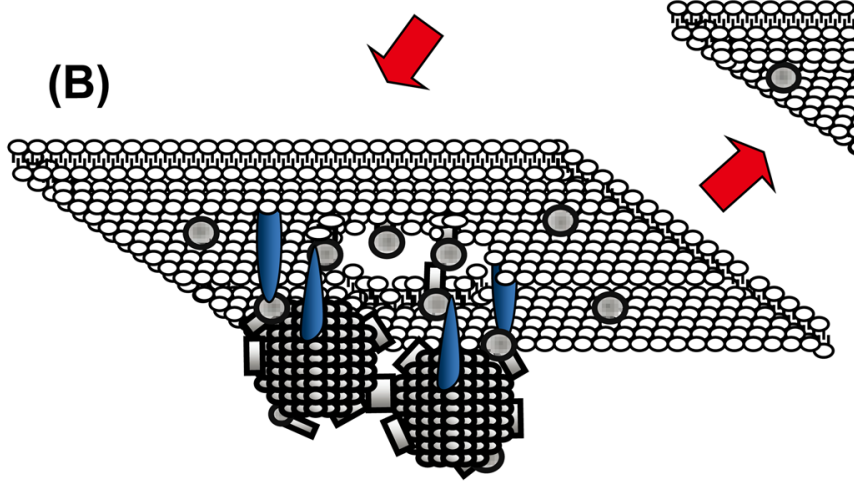

Fig. 3. Schema for a model of the membrane-resealing processes associated with dysferlin in vitro. (A) shows the intact condition. Membrane disruption leads to an influx of calcium ions (B). Transport of intracellular vesicles toward the damaged site by the motor proteins kinesin and myosin may be facilitated by mitsugumin 53 (MG53) in an oxidation/cholesterol-dependent manner. The vesicles dock through oxidized MG53 and fuse with each other and the plasma membrane, possibly with mediation by annexin, soluble $N$-ethylmaleimide-sensitive factor attachment protein receptors (SNAREs) and dysferlin in the presence of the calcium ion. Dysferlin interacts with annexins A1 and A2 and mediates wound healing of the sarcolemma. A membrane patch is consequently formed and reseals the membrane lesion (C). Although the proteins dysferlin and MG53 are known to be involved in muscle repair, there is still no direct evidence of an in vivo interaction between them.

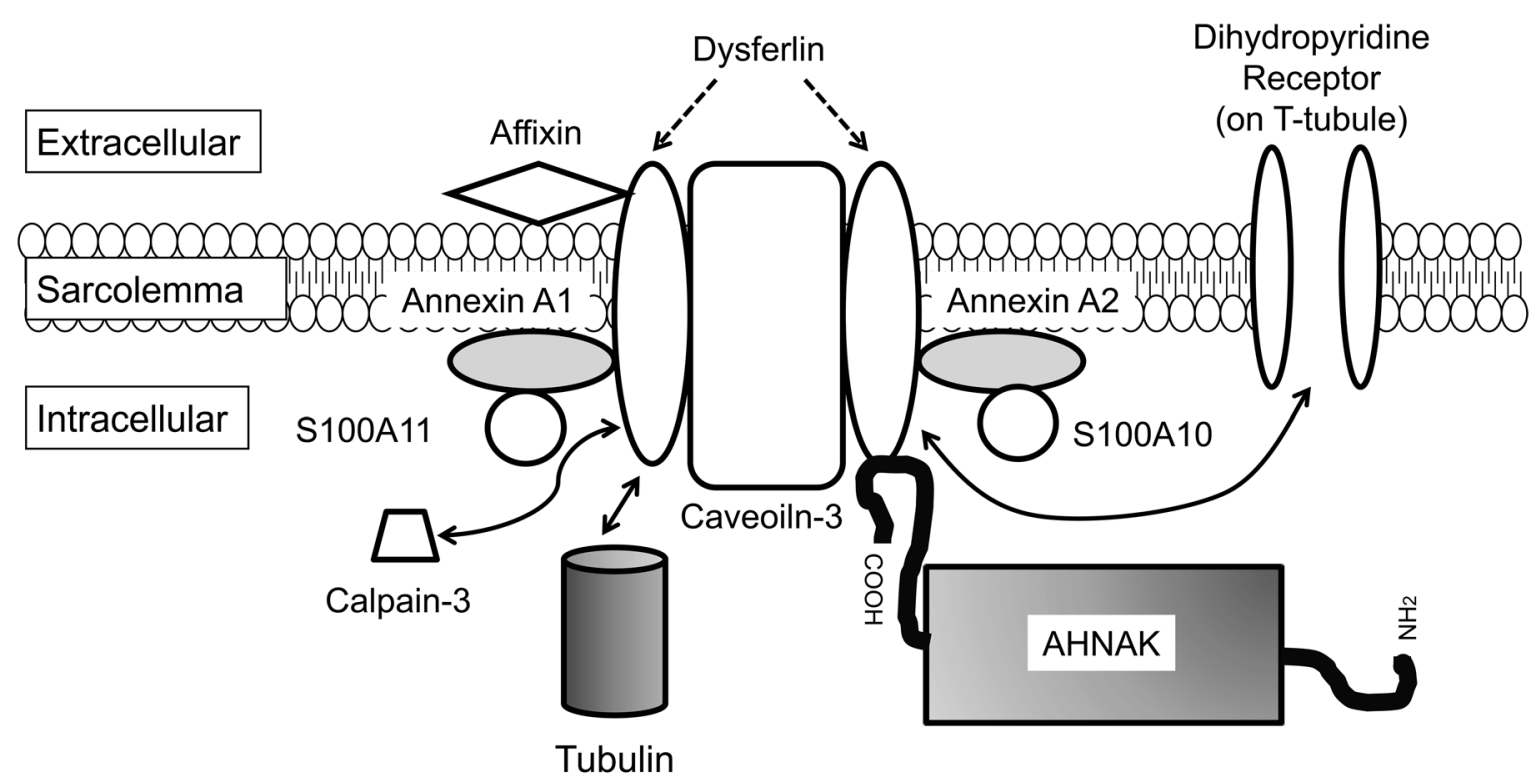

Fig. 4. Schema showing the interactions of proteins with dysferlin at the sarcolemma in skeletal muscle. 
$\mathrm{Ca}^{2+}$ signaling ${ }^{41}$. In contrast, it has been hypothesized that a deficiency of DYSF in mammalian skeletal muscles results in the release of ATP or other endogenous danger/alarm signals such as high-mobility group box-1 (HMGB1), S100 proteins or heat-shock proteins (HSPs), possibly through a compensatory vesicle-trafficking pathway mediated by the synaptotagmin-like protein Slp2a and the small GTPase Rab27A. It has also been suggested that the released factors activate an inflammatory pathway by means of toll-like receptors or a $\mathrm{P} 2 \mathrm{X} 7$ receptor (a mammalian ATP-gated nonselective cation channel $)^{42}$. In fact, $\mathrm{P} 2$ receptor antagonist lowered serum levels of CK and reduced muscle damage in dystrophin-deficient $m d x$ mice and in sarcoglycan-deficient BIO 14.6 hamsters ${ }^{43}$. Further studies are necessary to elucidate the relationship between releases of danger/alarm molecules and DYSF deficiency.

\section{The role of dysferlin in phagocytosis}

Monocytes derived from DYSF-deficient mice and from human patients with dysferlinopathy have been shown to promote phagocytic activity ${ }^{44}$. Knockdown of DYSF mRNA expression by RNA interference in the J774 macrophage cell line significantly enhanced this phagocytosis. Therefore, the accumulation of macrophages in muscles showing dystrophic changes may be a primary lesion caused by DYSF deficiency rather than a secondary lesion that occurs after muscle degeneration/necrosis. However, because muscle-specific transgenic expression of DYSF at appropriate levels suppresses the progression of dystrophic changes in dysferlin-deficient mice ${ }^{45,46}$, enhanced phagocytic activity alone in DYSF-deficient monocytes is considered to be insufficient to cause muscle damage.

\section{Animal Models for Dysferlinopathy}

Two naturally occurring animal models for LGMD2B have been identified: SJL/J (SJL) mice and A/J mice. These have been shown to have mutations in the DYSF gene associated with phenotypical features of progressive muscular dystrophy18,47. SJL mice have a splice site mutation in which part of the highly conserved C2E domain in DYSF is removed ${ }^{47}$. A/J mice bear a unique ETn retrotransposon insertion near the 5' end (intron 4) of the DYSF gene ${ }^{47}$.

\section{Characteristics of animal models for dysferlinopathy}

(1) Histopathological findings: Distribution of histopathological lesions:

Histopathological characteristics of animal models of dysferlinopathy include degeneration/necrosis of muscle fibers, variations in the size of muscle fibers, atrophy of muscle fibers, inflammatory cell infiltration, centronuclear fibers, fatty infiltration and fibrosis in the limb girdle (mainly the rectus femoris and lateral longissimus muscles) ${ }^{47-49}$.

Studies have also shown that there are differences between SJL and A/J mice in terms of the progress and prevalent sites of skeletal muscular lesions ${ }^{47,48}$. In particular, the difference between SJL and $\mathrm{A} / \mathrm{J}$ mice in their sensitivity to muscular dystrophic lesions was most apparent in their lumbar (longissimus and sublumbar) muscles. These findings support the hypothesis that, as well as a deficiency in DYSF, additional enhancers or modifiers might be involved in the progression of skeletal muscle lesions in dysferlinopathy. Figure 5 shows typical histopathological findings for the femoral muscles of SJL and A/J mice aged 10 and 30 weeks in comparison with normal BALB/c mice of the same age.

\section{(2) Histochemical findings: Typing of damaged mus-} cle fibers:

In dysferlin-deficient patients with an advanced-stage dystrophic pattern, a predominance (in excess of $80 \%$ ) of Type 1 (slow-twitch) fibers has been observed, suggesting a selective loss of Type 2 (fast-twitch) fibers or a process of conversion of Type 1 fibers into Type 2 fibers ${ }^{50}$. Similarly, histochemical staining for NADH-TR and SDH enzymes revealed that degeneration of fast-twitch muscle fibers was a predominant characteristic of SJL mice ${ }^{48}$. However, the medial vastus and iliocostalis muscles, which originally consisted mainly of fast-twitch muscle fibers, showed little degeneration/necrosis of muscle fibers. These findings indicate that the sensitivity of Type 2 fibers to injury might be site-specific, as seen in the rectus femoris and lateral longissimus muscles of SJL mice.

\section{(3) Immunohistochemical findings: Identification of infiltrating cells:}

Mononuclear cells found in or around degenerative and/ or necrotic muscle fibers show a positive reaction to mouse F4/80 antigen (widely used to identify mouse macrophages in lesions ${ }^{51,52}$ ) and must therefore be macrophages. A previous immunohistochemical analysis using an antibody to the Mac-1 $\alpha$-chain (also known as CD11b or integrin $\alpha_{M}$ chain) showed that macrophages were the predominant type of infiltrating cell in the muscles of SJL mice ${ }^{49}$. It is not known whether this macrophage infiltration at the muscle lesions occurs solely as a result of the uptake of cellular debris (such as necrotic muscle fibers) or is a consequence of enhanced phagocytosis of the target cells as a result of opsonization of the sarcolemma by $\mathrm{C} 3 \mathrm{~b}$.

\section{Gene expression profiling of animal models for dys- ferlinopathy}

(1) Endoplasmic reticulum stress-associated gene:

It has been reported that a novel mutant (L1341P) DYSF spontaneously aggregates in the endoplasmic reticulum (ER), resulting in phosphorylation of the eukaryotic translation-initiation factor subunit eIF $2 \alpha$ and conversion of microtubule-associated protein light chain 3 (LC3) until ER-stress-related cell death eventually occurs ${ }^{53}$. Moreover, it has been reported that ER dysfunction plays a significant role in the pathophysiology of several myopathies ${ }^{54-56}$. Therefore, to examine the relationship between ER stress and skeletal muscle lesions in SJL or $\mathrm{A} / \mathrm{J}$ mice, we have conducted a semiquantitative analysis of expression levels of spliced XBP1 mRNA as an ER stress marker in SJL mice ${ }^{48}$; 

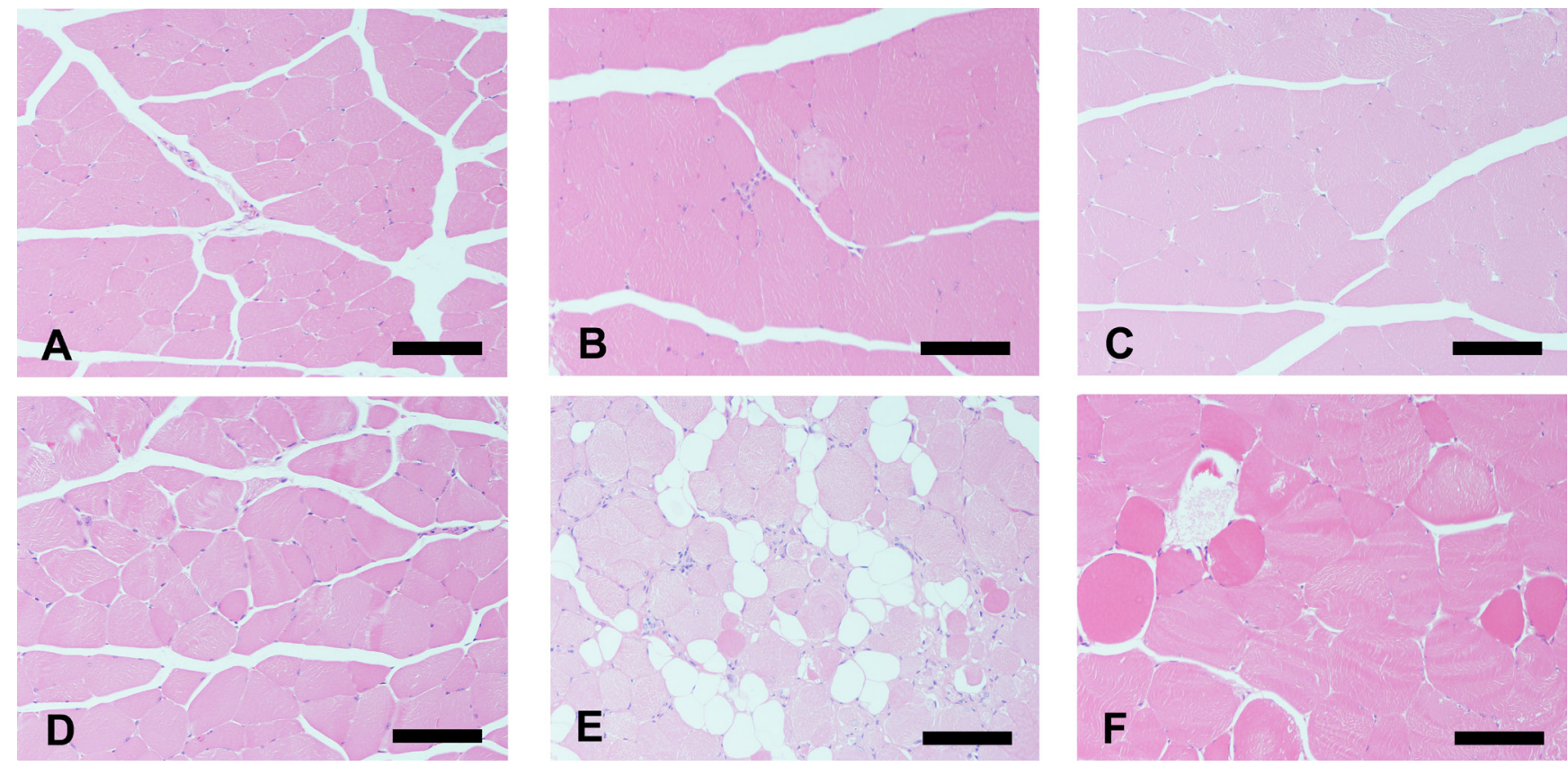

Fig. 5. Histopathology of the rectus femoris in BALB/c, SJL/J and A/J mice. At 10 weeks of age (upper figures), no significant changes were observed in the skeletal muscle fibers of BALB/c (A) and $\mathrm{A} / \mathrm{J}$ mice $(\mathrm{C})$, and a few muscle fibers showed minimal degeneration with mononuclear cell infiltration in SJL/J mice (B). At 30 weeks of age (lower figures), BALB/c mice did not exhibit histopathological changes in any skeletal muscles (D). The histopathological lesions of skeletal muscles in SJL/J mice progressed in severity with age and were characterized by the following findings: degenerative/necrotic muscle fibers, centronuclear muscle fibers, fatty infiltration and variations in the size of the muscle fibers (E). The muscle fibers in A/J mice showed only degenerative/necrotic features and variations in size (F). Hematoxylin and eosin (HE) staining. Bar: $100 \mu \mathrm{m}$.

we have also conducted an analysis of ER stress-associated genes (HSP5, Grp78, Atf6, and Chop) in SJL and A/J mice by means of a quantitative real-time polymerase chain reaction (qRT-PCR) using TaqMan ${ }^{\circledR}$ Gene Expression Assays ${ }^{57}$. Because these ER stress-associated gene expression analyses did not show any increases in gene expression, we consider that ER stress does not affect the progression of skeletal muscle lesions in SJL or $\mathrm{A} / \mathrm{J}$ mice in advanced stages of dysferlinopathy.

\section{(2) Lipid metabolism associated gene:}

A qRT-PCR study demonstrated that SJL mice tend to show increased expression of uncoupling protein 2 (Ucp2) in the rectus femoris and longissimus lumborum at 30 weeks of age, which is when dystrophic lesions become histopathologically pronounced 57 .

Forced expression of Ucp2 in pancreatic islets resulted in a decreased content of ATP, and the islet cells of Ucp2 knockout mice showed increased levels of ATP ${ }^{58}$. Overexpression of UCP2 in primary cardiomyocytes led to a significant decline in the ATP level and an enhanced sensitivity to hypoxia-reoxygenation ${ }^{59}$. Ucp2-mediated energy loss may be related to muscle degeneration/necrosis in SJL mice. On the other hand, Tbcldl gene-deficient cells exhibited inhibited trafficking of the glucose transporter GLUT4 from intracellular vesicles to the plasma membrane ${ }^{60}$, suggesting a decrease in intracellular glucose levels and a subsequent enhancement of fatty acid oxidation. These results suggest that the Tbcldl gene-deficient skeletal muscles in SJL mice ${ }^{61}$ are likely to show uncoupling.

(3) Anti-oxidative stress-associated genes and heatshock protein genes:

Heme oxygenase 1 (Hmox1) was upregulated in the rectus femoris, longissimus lumborum and abdominal muscles at 30 weeks of age; dystrophic lesions occur more commonly in these muscles in SJL mice ${ }^{57}$. The gene expression levels of HSP70 in most muscles of $\mathrm{A} / \mathrm{J}$ mice were lower than those in BALB/c mice used as controls.

Hmox 1 provides the first line of defense against oxidative stress, because it responds rapidly to oxidants ${ }^{62}$. However, Txnrd1, which (together with Hmox1) is a part of the anti-oxidation system, was not upregulated in any muscles of SJL mice. Recently, Ca-dependent upregulation of Hsp70 and Hmox-1 in skeletal muscle cells and in hepatocytes has been reported ${ }^{63,64}$. Because DYSF-null muscle fibers are defective in $\mathrm{Ca}^{2+}$-dependent resealing of disruptions of the sarcolemma ${ }^{19}$, these muscle fibers may cause persistent influx of $\mathrm{Ca}$ into the cytoplasm after membrane injury. The gene expression levels of Hmox1 were correlated with the severity of histopathological lesions in femoral (rectus femoris), lumbar (longissimus lumborum) and abdominal muscles; therefore, $\mathrm{Ca}$ influx into the cytoplasm following muscle injury may induce Hmoxl gene expression. However, Hsp70 was also upregulated in the diaphragms of SJL mice, where few histopathological changes were observed at 
Table 1. Changes of Gene Expression and Prospective Events in SJL and A/J Mice

\begin{tabular}{clll}
\hline Strain & \multicolumn{1}{c}{ Cause } & Change of gene expression & \multicolumn{1}{c}{ Prospective event } \\
\hline SJL & Gene mutation (frame shift deletion) & Dysferlin: $\downarrow$ & Membrane repair function: $\downarrow$ \\
& Fatty acid oxidation: $\uparrow$ & Ucp $: \uparrow$ & ATP production: $\downarrow$ \\
& Muscle fiber injury: $\uparrow$ & Hmox $1: \uparrow$ & Cellular protective activity: $\uparrow$ \\
& Unknown & S100A4: $\uparrow$ & Macrophage recruitment/chemotaxis: $\uparrow$ \\
& Unknown & Daf1/CD55: $\downarrow$ & Sensitivity to complement-dependent cytotoxicity: $\uparrow$ \\
\hline \multirow{2}{*}{ A/J } & Gene mutation (transposon insertion) & Dysferlin: $\downarrow$ & Membrane repair function: $\downarrow$ \\
& Dysferlin: $\downarrow(?)$ & Hsp70: $\downarrow$ & Cellular protective activity: $\downarrow$ \\
\hline
\end{tabular}

any stage when this was examined. In addition, no change in the level of expression of the $H s p 70$ gene was observed in abdominal muscles of SJL mice in where histopathological changes were observed at 30 weeks of age. The muscles and hearts in histopathologically normal BALB/c mice exhibited upregulation of the expression of this gene from 15 weeks of age ${ }^{57}$. It has been reported that significant increases in Hsp70 are observed at 12 weeks postpartum in normal rats $^{65}$. The physiological mechanism of the expression of the $H s p 70$ gene may develop somewhat later in noncardiac muscles of SJL mice; therefore, an unknown factor in addition to persistent $\mathrm{Ca}$ influx may cause Hmox1 induction in these muscles of SJL mice.

In contrast, the levels of expression of the $H s p 70$ gene in most muscles of $\mathrm{A} / \mathrm{J}$ mice were lower than those in the control. Loss of fer-1, a DYSF homolog, in C. elegans causes downregulation of $h s p-70^{66}$. It is possible that the downregulation of $H s p 70$ gene expression in the skeletal muscles of $\mathrm{A} / \mathrm{J}$ mice is caused by a functional loss of DYSF.

(4) Ca-binding protein gene:

S100 calcium-binding protein A4 (S100A4) was upregulated in the rectus femoris, longissimus lumborum and abdominal muscles in SJL mice at 30 weeks of age ${ }^{57}$; these are the muscles in which dystrophic lesions occur most commonly in these mice ${ }^{48}$. These upregulations of S100A4 coincide approximately with the occurrence of dystrophic changes in the associated lesions. Most of the infiltrating cells in muscle lesions in SJL mice are F4/80 antigen-positive macrophages ${ }^{48}$. Recently, it has been demonstrated that S100A4 mediates macrophage recruitment and chemotaxis in vivo ${ }^{67}$. Upregulation of S100A4 in the rectus femoris and longissimus lumborum of SJL mice may be linked to the pathological characteristics of muscle in SJL mice.

\section{(5) Complement control factor gene:}

In comparison with $\mathrm{BALB} / \mathrm{c}$ mice, SJL mice of all ages showed a marked lowering of the expression of Dafll $C D 55$ gene in all studied muscles, except for the heart ${ }^{57}$. In contrast, there was no predominant difference in the levels of Dafl/CD55 gene expression in A/J mice compared with those in $\mathrm{BALB} / \mathrm{c}$ mice $\mathrm{e}^{57}$. As previously indicated, it has been reported that gene expression of Dafl/CD55 as a complement inhibitor is downregulated in the skeletal muscles of LGMD2B patients and in those of SJL mice68. Moreover, the serum concentration of C5 in SJL mice is known to be significantly greater than that in other strains ${ }^{69}$. On the other hand, $\mathrm{A} / \mathrm{J}$ mice are genetically deficient in $\mathrm{C} 5^{70}$. At the time of the study, we understood that the difference in phenotype between the two DYSF-deficient mice was related to the presence or absence of $\mathrm{C} 5$; however, it was later revealed that genetic ablation of $\mathrm{C} 5$ had a minimal effect on muscle lesions in DYSF-deficient mice ${ }^{45}$.

Table 1 lists gene expression and prospective events in $\mathrm{SJL}$ and $\mathrm{A} / \mathrm{J}$ mice. It has also been reported that differential gene expression profiles of proximal and distal muscle groups are altered in prepathological C57BL/10.SJL-Dysf mice $^{71}$. Furthermore, the expression profiles of 10,012 genes in the quadriceps femoris muscles of control and SJL mice have been established by means of a cDNA microarray analysis, with the aim of identifying genes that are involved in the degeneration and regeneration process and in the functional network of dysferlin ${ }^{72}$. However, it cannot be stated with confidence that common factors associated with muscular changes in dysferlinopathy were discovered in these studies (including our own), and further investigations are required to determine whether alterations in gene expression levels are the cause of dystrophic changes or they occur as a result of damage to the muscle.

\section{Problems associated with animal models for dysfer- linopathy}

In general, murine models for muscular dystrophies, including SJL and A/J mice, do not show any significant muscle weakness. This makes it difficult to evaluate improved muscle strength, and therefore, the screening of therapies by using murine models depends exclusively on histopathological examination.

Because it is simple to induce autoimmune diseases in SJL mice, they have been used as animal models for autoimmunological diseases such as experimental autoimmune encephalomyelitis ${ }^{73}$, experimental autoimmune myositis ${ }^{74}$, and experimental autoimmune hypophysitis ${ }^{75}$. In addition, it has been reported that SJL mouse-derived monocytes increase phagocytic activity ${ }^{76}$ and that dysferlin deficiency induces an upregulation of inflammasome ${ }^{42}$. However, a more recent study using C57BL/10-SJL.Dysf mice, which have a more controlled genetic background, did not find any change in the phagocytic activity of dysferlin-deficient monocytes ${ }^{77}$. A/J mice, on the other hand, show later onset of muscle lesions than do SJL mice or DYSF-deficient mice with the genetic background $129 \mathrm{SvJ}$, and the lumbar mus- 
cles of SJL and $\mathrm{A} / \mathrm{J}$ mice showed a difference in their sensitivity to muscular dystrophic lesions. There is a concern therefore that differences in the genetic or immunological background of SJL and A/J mice could cause modifications in the nature of any muscle damage.

As pointed out above, the two strains show phenotypic divergences. A/J mice display a later onset and a slower progression of muscular disease compared with SJL mice ${ }^{47,48}$, and the two strains show differences in their gene expression profiles. Similarly, dysferlinopathies in humans are a clinically heterogeneous group of disorders ${ }^{78}$. It has been considered that through probing of the causes of interstrain differences, A/J and SJL strains of mice might prove useful in providing clues regarding the causes of clinical heterogeneity in humans and in identifying targets for stopping or slowing the progression of the disease. At present, however, we have little knowledge of the causes of interstrain differences.

\section{Development of Therapies for Muscular Dystro- phies, Including Dysferlinopathy}

\section{Transfection of cDNA by plasmid vectors}

Plasmid vectors can transfer large cDNA fragments (for example, full-length dystrophin cDNA) and they are noninfectious and nonimmunogenic ${ }^{8}$. Although these characteristics are major advantages compared with viral vectors, plasmid vectors provide less-efficient transfection than do viral vectors.

\section{Transfection of $c D N A$ by viral vectors}

The AAV vector is currently one of the most promising viral vectors for transfection of cDNA. AAV can package and protect recombinant DNA strands as large as $6.0 \mathrm{~kb}$, but virions carrying larger DNA strands are preferentially degraded by the proteasome ${ }^{79}$. Furthermore, AAV vectors can induce immune reactions ${ }^{80,81}$.

In gene therapy for LGMD2B, the size of the dysferlin cDNA prevents its direct incorporation into an AAV vector for therapeutic gene transfer into muscle. To bypass this limitation, Lostal et al. have split dysferlin cDNA at the exon 28/29 junction and have cloned it into two independent AAV vectors, each carrying the appropriate splicing sequences ${ }^{82}$. Intramuscular injection of the corresponding vectors into a dysferlin-deficient mouse led to the expression of full-length dysferlin for at least 1 year.

\section{Exon skipping by antisense oligonucleotides}

Exon skipping by antisense oligonucleotides is among the most advanced therapies for muscular dystrophy (especially DMD). GSK-2402968 is currently advancing to Phase III clinical trials (http://clinicaltrials.gov/ct2/results?term $=$ GSK-2402968), and a Phase II study of AVI-4658 is ongoing (http://clinicaltrials.gov/ct2/ results?term=AVI-4658). However, exon skipping by antisense oligonucleotides has some disadvantages ${ }^{8}$ in that the therapy needs regular repeated administration because the method modifies only the process of mRNA splicing, and different antisense oligonucleotides are needed for different types of dystrophin gene deletion.

\section{Stem or progenitor cell transplantation}

Myoblasts/satellite cells, hematopoietic stem cells, mesenchymal stem cells, bone-marrow side population, muscle side population, muscle-derived stem cells, adiposederived stem cells, endothelial progenitor cells and vesselassociated stem cells have all been studied for their possible use in cell-based therapies ${ }^{11,83}$. Several clinical trials involving injection of myoblasts or pericytes from HLA-matched donors have begun or are planned, and the number of such trials will increase in the near future ${ }^{11}$; however, little information is currently available regarding the safety and efficacy of these techniques in clinical use.

In a study of a cell-based therapy for LGMD2B, human and mouse dysferlin proteins were detected one month after transplantation in all SCID mice transplanted with normal human myoblasts and in SJL mice transplanted with allogeneic primary mouse muscle cell culture ${ }^{84}$. The number of dysferlin-positive fibers was $40-50 \%$ and $20-30 \%$ in SCID and SJL muscle sections, respectively. In another study, it was shown immunohistochemically that a small number of human cells from human umbilical cord blood became grafted into recipient SJL mice muscle and expressed both dysferlin and human-specific dystrophin 12 weeks after transplantation 85 .

\section{Read-through by small-molecule drugs}

Phase IIb trials of ataluren (PTC124), which causes read-through for the nonsense mutation $\mathrm{DMD} / \mathrm{BMD}$, has been suspended or terminated because the primary endpoint did not reach statistical significance within the 48week duration of the study (http://clinicaltrials.gov/ct2/ results?term $=$ PTC124).

\section{Antibody treatment}

A safety trial of a neutralizing antibody to myostatin, MYO-029, has been conducted in adult muscular dystrophies (Becker muscular dystrophy, facioscapulohumeral dystrophy and LGMD) ${ }^{86}$. Although MYO-029 has good safety and high tolerability, no improvements were noted in the exploratory end points of muscle strength and function. This probably occurred because the study was not designed to seek efficacy.

In a study of an antibody therapy for LGMD2B, administration of an antibody for tumor necrosis factor (TNF) resulted in dose-dependent reductions in inflammatory change, necrosis and fatty/fibrous change. These findings suggest that TNF does indeed play a role in damage to muscle in SJL mice 87 .

Because these therapeutic methods for dysferlinopathy are still not under evaluation in clinical studies, immediate development of a therapy for dysferlinopathy is a desirable goal. 


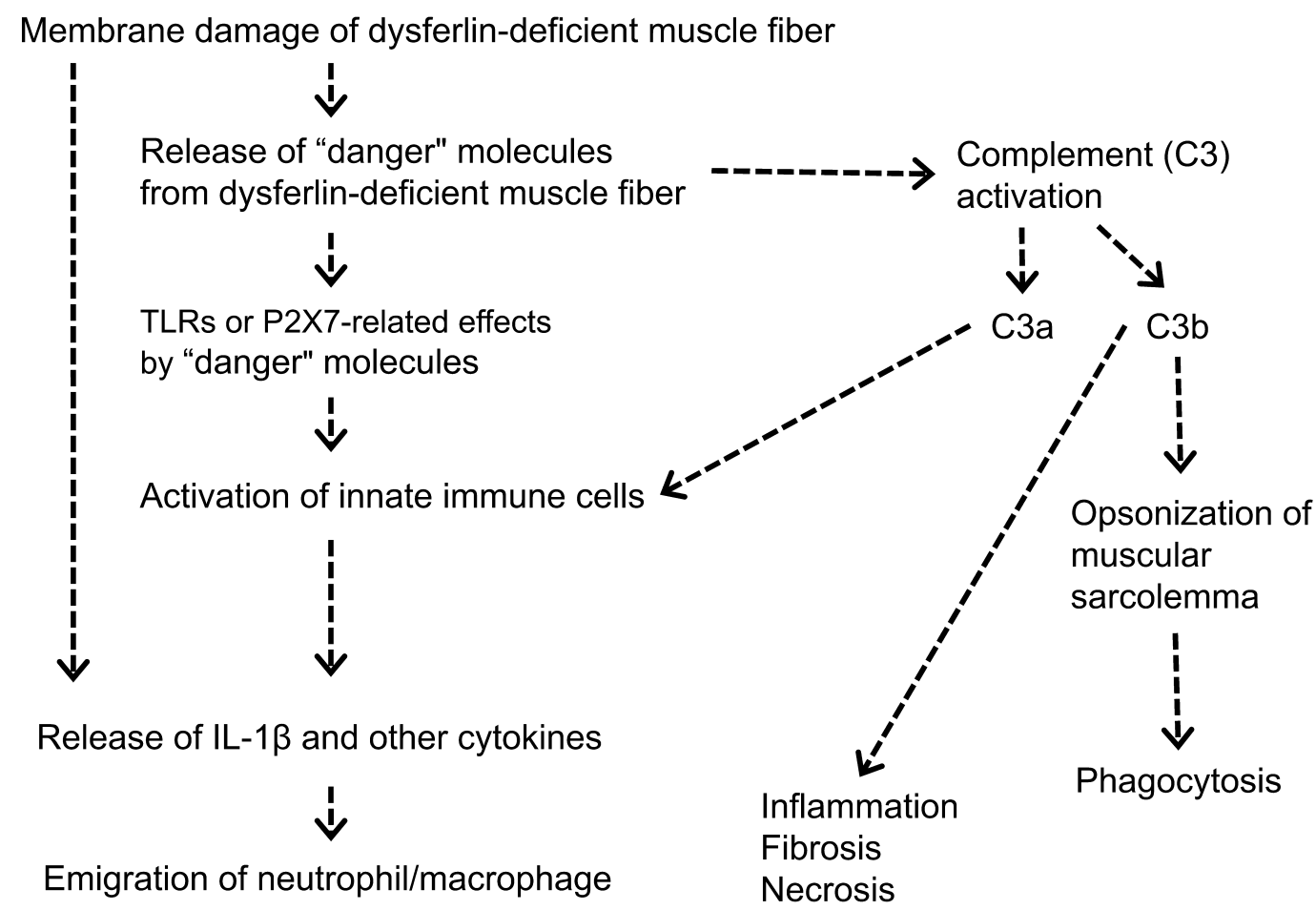

Fig. 6. Estimated inflammatory process in dysferlin-deficient skeletal muscle. Plasma membrane damage to dysferlin-deficient muscle fibers causes a release of "danger" molecules (heat-shock proteins, high mobility group box-1, ATP, etc.). These "danger" molecules are recognized by receptors on innate immune cells and muscle cells and they stimulate the production of proinflammatory cytokines. Moreover, the released "danger" molecules activate the complement system and stimulate C3a or opsonizing C3b. The proinflammatory mediator $\mathrm{C} 3 \mathrm{a}$ can trigger the production of proinflammatory cytokines from cells and render the local vascular endothelium "leaky"; this is followed by attraction of the migration of neutrophils and macrophages. C3b binds to the negatively charged sarcolemma, stimulating phagocytosis. These processes cause more-severe muscular degeneration/necrosis.

\section{Identification of New Therapeutic Targets for Dysferlinopathy by Using Animal Models}

\section{Complement-associated factors}

Complement factors are upregulated or activated in DYSF-deficient muscles from mice and humans ${ }^{45,68}$. This upregulation of complement factors was observed in DYSFdeficient mice before the onset of the obvious pathological markers and was normalized by muscle-specific expression of the DYSF transgene ${ }^{45}$. To confirm whether or not an activated complement system causes skeletal muscle damage, a gene for complement factor $\mathrm{C} 3$ or $\mathrm{C} 5$ was disrupted in DYSF-deficient mice ${ }^{45}$. Whereas genetic ablation of $\mathrm{C} 5 \mathrm{had}$ a minimal effect on muscle lesions in DYSF-deficient mice, a deficiency in $\mathrm{C} 3$ ameliorated histopathological changes in the skeletal muscles. In addition, deposition of $\mathrm{C} 3$ on the sarcolemma of quadriceps muscles in DYSF-deficient mice was confirmed by means of immunofluorescence analysis, whereas this staining pattern was not observed in DYSF/C3 double-deficient or wild-type mice. These results suggest that activated $\mathrm{C} 3$ is responsible for muscle damage in dysferlinopathy. $\operatorname{Han}^{88}$ has proposed a mechanism for muscle damage caused by active $\mathrm{C} 3$, in which $\mathrm{C} 3$ is cleaved into $\mathrm{C} 3 \mathrm{a}$ and $\mathrm{C} 3 \mathrm{~b}$ on activation of the complement system. $\mathrm{C} 3 \mathrm{a}$ is an anaphylotoxin that produces a local inflammatory response, whereas $\mathrm{C} 3 \mathrm{~b}$ serves as an opsonizing agent by coating the sarcolemma of dysferlin-deficient muscle. Opsonization of the sarcolemma, either with or without $\mathrm{C} 5$, enhances the phagocytosis of the target cell by macrophages, which are the predominant infiltrating cells in dysferlin-deficient muscles 48,89 . Figure 6 shows an estimated inflammatory process in dysferlin-deficient skeletal muscle.

Downregulation of decay-accelerating factor 1 (Daf1; also known as CD55), which acts as the complement inhibitor, induces increased susceptibility to complement attack in DYSF-deficient muscle cells ${ }^{68}$. However, in our study, SJL mice of all ages showed a marked downregulation of Dafl/ CD55 gene expression in skeletal muscles lacking obvious histopathological lesions ${ }^{57}$. Additionally, A/J mice showed no abnormality in Dafl/CD55 gene expression levels in their skeletal muscles with histopathological lesions ${ }^{57}$. For these reasons, downregulation of Dafl/CD55 alone cannot explain muscle damage in DYSF-deficient mice.

\section{Endogenous danger/alarm factors}

As previously mentioned, it has been proposed that DYSF deficiency in skeletal muscles results in release of endogenous danger/alarm signals, including HSPs, HMGB1 
and ATP. These factors bind to the toll-like receptor P2X7, activating inflammasome ${ }^{41}$, nuclear factor kappa-B and the complement pathways ${ }^{45}$. It is known that HSPs are antibody-dependently and antibody-independently activated in the complement system ${ }^{90}$. It has been reported that HMGB1 causes an irreversible decrease in the release of $\mathrm{Ca}^{2+}$ from the sarcoplasmic reticulum in vitro ${ }^{91}$. If the role of these factors in dysferlinopathy can be elucidated, the resulting knowledge may be helpful in preventing the progression of muscular lesions.

\section{Conclusion}

DYSF is involved in the membrane-repair process, intracellular vesicle system and development of T-tubules in skeletal muscles, and it interacts with MG53, annexins, caveolin-3, AHNAK, affixin, S100A10, calpain-3, tubulin and DHPR. In humans, a deficiency in DYSF induces dystrophic changes in the skeletal muscles of the limb girdle, the socalled LGMD2B and MM (which are collectively known as dysferlinopathy). LGMD2B occurs at a relatively high frequency in Japan, to the extent that the National Center of Neurology and Psychiatry stated in 2010 that dysferlinopathy has become the most common type of LGMD among the Japanese population. Because no therapeutic methods for dysferlinopathy are currently under evaluation in clinical studies, the immediate development of a therapy for dysferlinopathy is desirable. SJL and A/J mice are known to be naturally occurring animal models for dysferlinopathy. These models are therefore useful in verification experiments for new therapies and are valuable tools for identifying factors that accelerate dystrophic changes in skeletal muscle. However, it should be borne in mind that the genetic or immunological background of SJL or $\mathrm{A} / \mathrm{J}$ mice could result in modifications of muscle damage in experiments involving these animal models.

Acknowledgments: The authors thank Dr Kimiaki Hirakawa (Shin Nippon Biomedical Laboratories, Ltd.) for his valuable comments.

\section{References}

1. Cohn RD, and Campbell KP. Molecular basis of muscular dystrophies. Muscle Nerve. 23: 1456-1471. 2000. [Medline] [CrossRef]

2. Bushby KM. Making sense of the limb-girdle muscular dystrophies. Brain. 122: 1403-1420. 1999. [Medline] [CrossRef]

3. Han R, Bansal D, Miyake K, Muniz VP, Weiss RM, McNeil PL, and Campbell KP. Dysferlin-mediated membrane repair protects the heart from stress-induced left ventricular injury. J Clin Invest. 117: 1805-1813. 2007. [Medline] [CrossRef]

4. Glover L, and Brown RH Jr. Dysferlin in membrane trafficking and patch repair. Traffic. 8: 785-794. 2007. [Medline] [CrossRef]
5. Centers for Disease Control and Prevention (CDC). Prevalence of Duchenne/Becker muscular dystrophy among males aged 5-24 years - four states, 2007. Morb Mortal Wkly Rep. 58: 1119-1122. 2009.

6. Sunada Y. Limb-girdle muscular dystrophy: Update. Rinsho Shinkeigaku. 44: 995-997. 2004. [Article in Japanese] [Medline]

7. Hayashi S, Ohsawa Y, Takahashi T, Suzuki N, Okada T, Rikimaru M, Murakami T, Aoki M, and Sunada Y. Rapid screening for Japanese dysferlinopathy by fluorescent primer extension. Intern Med. 49: 2693-2696. 2010. [Medline] [CrossRef]

8. Park KS, and Oh D. Gene therapy for muscular dystrophy: Progress and challenges. J Clin Neurol. 6: 111-116. 2010. [Medline] [CrossRef]

9. Cirak S, Arechavala-Gomeza V, Guglieri M, Feng L, Torelli S, Anthony K, Abbs S, Garralda ME, Bourke J, Wells DJ, Dickson G, Wood MJ, Wilton SD, Straub V, Kole R, Shrewsbury SB, Sewry C, Morgan JE, Bushby K, and Muntoni F. Exon skipping and dystrophin restoration in patients with Duchenne muscular dystrophy after systemic phosphorodiamidate morpholino oligomer treatment: An open-label, Phase 2, dose-escalation study. Lancet. 378: 595-605. 2011. [Medline] [CrossRef]

10. Hammond SM, and Wood MJ. PRO-051, an antisense oligonucleotide for the potential treatment of Duchenne muscular dystrophy. Curr Opin Mol Ther. 12: 478-486. 2010. [Medline]

11. Quattrocelli M, Cassano M, Crippa S, Perini I, and Sampaolesi M. Cell therapy strategies and improvements for muscular dystrophy. Cell Death Differ. 17: 1222-1229. 2010. [Medline] [CrossRef]

12. Arakawa M, Shiozuka M, Nakayama Y, Hara T, Hamada M, Kondo S, Ikeda D, Takahashi Y, Sawa R, Nonomura Y, Sheykholeslami K, Kondo K, Kaga K, Kitamura T, SuzukiMiyagoe Y, Takeda S, and Matsuda R. Negamycin restores dystrophin expression in skeletal and cardiac muscles of $m d x$ mice. J Biochem. 134: 751-758. 2003. [Medline] [CrossRef]

13. De Luca A, Nico B, Rolland JF, Cozzoli A, Burdi R, Mangieri D, Giannuzzi V, Liantonio A, Cippone V, De Bellis M, Nicchia GP, Camerino GM, Frigeri A, Svelto M, and Camerino DC. Gentamicin treatment in exercised $m d x$ mice: Identification of dystrophin-sensitive pathways and evaluation of efficacy in work-loaded dystrophic muscle. Neurobiol Dis. 32: 243-253. 2008. [Medline] [CrossRef]

14. Nudelman I, Rebibo-Sabbah A, Cherniavsky M, Belakhov V, Hainrichson M, Chen F, Schacht J, Pilch DS, Ben-Yosef $\mathrm{T}$, and Baasov T. Development of novel aminoglycoside (NB54) with reduced toxicity and enhanced suppression of disease-causing premature stop mutations. J Med Chem. 52: 2836-2845. 2009. [Medline] [CrossRef]

15. Finkel RS. Read-through strategies for suppression of nonsense mutations in Duchenne/Becker muscular dystrophy: Aminoglycosides and ataluren (PTC124). J Child Neurol. 25: 1158-1164. 2010. [Medline] [CrossRef]

16. Nishida A, Kataoka N, Takeshima Y, Yagi M, Awano H, Ota M, Itoh K, Hagiwara M, and Matsuo M. Chemical treatment enhances skipping of a mutated exon in the dystrophin gene. Nat Commun. 2: 308. 2011. [Medline] [CrossRef]

17. Bogdanovich S, Krag TO, Barton ER, Morris LD, Whittemore LA, Ahima RS, and Khurana TS. Functional im- 
provement of dystrophic muscle by myostatin blockade. Nature. 420: 418-421. 2002. [Medline] [CrossRef]

18. Bittner RE, Anderson LV, Burkhardt E, Bashir R, Vafiadaki E, Ivanova S, Raffelsberger T, Maerk I, Hoger H, Jung M, Karbasiyan M, Storch M, Lassmann H, Moss JA, Davison K, Harrison R, Bushby KM, and Reis A. Dysferlin deletion in SJL mice (SJL-Dysf) defines a natural model for limb girdle muscular dystrophy 2B. Nat Genet. 23: 141-142. 1999. [Medline] [CrossRef]

19. Bansal D, Miyake K, Vogel SS, Groh S, Chen CC, Williamson R, McNeil PL, and Campbell KP. Defective membrane repair in dysferlin-deficient muscular dystrophy. Nature. 423: 168-172. 2003. [Medline] [CrossRef]

20. McNeil PL, Miyake K, and Vogel SS. The endomembrane requirement for cell surface repair. Proc Natl Acad Sci USA. 100: 4592-4597. 2003. [Medline] [CrossRef]

21. Bi GQ, Alderton JM, and Steinhardt RA. Calcium-regulated exocytosis is required for cell membrane resealing. $\mathrm{J}$ Cell Biol. 131: 1747-1758. 1995. [Medline] [CrossRef]

22. Miyake K, and McNeil PL. Vesicle accumulation and exocytosis at sites of plasma membrane disruption. J Cell Biol. 131: 1737-1745. 1995 [Medline] [CrossRef]

23. Bi GQ, Morris RL, Liao G, Alderton JM, Scholey JM, and Steinhardt RA. Kinesin- and myosin-driven steps of vesicle recruitment for $\mathrm{Ca}^{2+}$ regulated exocytosis. J Cell Biol. 138: 999-1008. 1997. [Medline] [CrossRef]

24. Togo T, and Steinhardt RA. Nonmuscle myosin IIA and IIB have distinct functions in the exocytosis-dependent process of cell membrane repair. Mol Biol Cell. 15: 688-695. 2004. [Medline] [CrossRef]

25. Cacciottolo M, Belcastro V, Laval S, Bushby K, di Bernardo $\mathrm{D}$, and Nigro $\mathrm{V}$. Reverse engineering gene network identifies new dysferlin-interacting proteins. J Biol Chem. 286: 5404-5413. 2011. [Medline] [CrossRef]

26. Lennon NJ, Kho A, Bacskai BJ, Perlmutter SL, Hyman BT, and Brown RH Jr. Dysferlin interacts with annexins A1 and A2 and mediates sarcolemmal wound-healing. J Biol Chem. 278: 50466-50473. 2003. [Medline] [CrossRef]

27. Weisleder N, Takeshima H, and Ma J. Mitsugumin 53 (MG53) facilitates vesicle trafficking in striated muscle to contribute to cell membrane repair. Commun Integr Biol. 2: 225-226. 2009. [Medline] [CrossRef]

28. Cai C, Weisleder N, Ko JK, Komazaki S, Sunada Y, Nishi M, Takeshima H, and Ma J. Membrane repair defects in muscular dystrophy are linked to altered interaction between MG53, caveolin-3 and dysferlin. J Biol Chem. 284: 15894-15902. 2009. [Medline] [CrossRef]

29. Cai C, Masumiya H, Weisleder N, Pan Z, Nishi M, Komazaki S, Takeshima $\mathrm{H}$, and Ma J. MG53 regulates membrane budding and exocytosis in muscle cells. J Biol Chem. 284: 3314-3322. 2009. [Medline] [CrossRef]

30. Cai C, Masumiya H, Weisleder N, Matsuda N, Nishi M, Hwang M, Ko JK, Lin P, Thornton A, Zhao X, Pan Z, Komazaki S, Brotto M, Takeshima H, and Ma J. MG53 nucleates assembly of cell membrane repair machinery. Nat Cell Biol. 11: 56-64. 2009. [Medline] [CrossRef]

31. Wang X, Xie W, Zhang Y, Lin P, Han L, Han P, Wang Y, Chen Z, Ji G, Zheng M, Weisleder N, Ziao RP, Takeshima $\mathrm{H}$, Ma J, and Cheng H. Cardioprotection of ischemia/reperfusion injury by cholesterol-dependent MG53-mediated membrane repair. Circ Res. 107: 76-83. 2010. [Medline] [CrossRef]
32. Cao CM, Zhang Y, Weisleder N, Ferrante C, Wang X, Lv F, Song R, Hwang M, Jin L, Guo J, Peng W, Li G, Nishi M, Takeshima H, Ma J, and Xiao RP. MG53 constitutes a primary determinant of cardiac ischemic preconditioning. Circulation. 121: 2565-2574, 2010. [Medline] [CrossRef]

33. Huang Y, Laval SH, van Remoortere A, Baudier J, Benaud C, Anderson LV, Straub V, Deelder A, Frants RR, den Dunnen JT, Bushby K, and van der Maarel SM. AHNAK, a novel component of the dysferlin protein complex, redistributes to the cytoplasm with dysferlin during skeletal muscle regeneration. FASEB J. 21: 732-742. 2007. [Medline] [CrossRef]

34. Matsuda C, Kameyama K, Tagawa K, Ogawa M, Suzuki A, Yamaji S, Okamoto H, Nishino I, and Hayashi YK. Dysferlin interacts with affixin (beta-parvin) at the sarcolemma. J Neuropathol Exp Neurol. 64: 334-340. 2005. [Medline]

35. Rezvanpour A, and Shaw GS. Unique S100 target protein interactions. Gen Physiol Biophys. 28 Spec No Focus: F39F46. 2009. [Medline]

36. Huang Y, de Morrée A, van Remoortere A, Bushby K, Frants RR, Dunnen JT, and van der Maarel SM. Calpain 3 is a modulator of the dysferlin protein complex in skeletal muscle. Hum Mol Genet. 17: 1855-1866. 2008. [Medline] [CrossRef]

37. Azakir BA, Di Fulvio S, Therrien C, and Sinnreich M. Dysferlin interacts with tubulin and microtubules in mouse skeletal muscle. PLoS One. 5: e10122. 2010. [Medline] [CrossRef]

38. Ampong BN, Imamura $\mathrm{M}$, Matsumiya $\mathrm{T}$, Yoshida $\mathrm{M}$, and Takeda S. Intracellular localization of dysferlin and its association with the dihydropyridine receptor. Acta Myol. 24: 134-144. 2005. [Medline]

39. Klinge L, Laval S, Keers S, Haldane F, Straub V, Barresi R, and Bushby K. From T-tubule to sarcolemma: Damage-induced dysferlin translocation in early myogenesis. FASEB J. 21: 1768-1776. 2007. [Medline] [CrossRef]

40. Klinge L, Hams J, Sewry C, Charlton R, Anderson L, Laval S, Chiu YH, Homsey M, Straub V, Barresi R, Lochmüller $\mathrm{H}$, and Bushby K. Dysferlin associates with the developing T-tubule system in rodent and human skeletal muscle. Muscle Nerve. 41: 166-173. 2010. [Medline] [CrossRef]

41. Covian-Nares JF, Koushik SV, Puhl HL 3rd, and Vogel SS. Membrane wounding triggers ATP release and dysferlinmediated intercellular calcium signaling. J Cell Sci. 123: 1884-1893. 2010. [Medline] [CrossRef]

42. Rawat R, Cohen TV, Ampong B, Francia D, Henriques-Pons A, Hoffman EP, and Nagaraju K. Inflammasome up-regulation and activation in dysferlin-deficient skeletal muscle. Am J Pathol. 176: 2891-2900. 2010. [Medline] [CrossRef]

43. Iwata Y, Katanosaka Y, Hisamitsu T, and Wakabayashi S. Enhanced $\mathrm{Na}^{+} / \mathrm{H}^{+}$exchange activity contributes to the pathogenesis of muscular dystrophy via involvement of P2 receptors. Am J Pathol. 171: 1576-1587. 2007. [Medline] [CrossRef]

44. Nagaraju K, Rawat R, Veszalovszky E, Thapliyal R, Kesari A, Sparks S, Raben N, Plotz P, and Hoffman EP. Dysferlin deficiency enhances monocyte phagocytosis: A model for the inflammatory onset of limb-girdle muscular dystrophy 2B. Am J Pathol. 172: 774-785. 2008. [Medline] [CrossRef]

45. Han R, Frett EM, Levy JR, Rader EP, Lueck JD, Bansal D, Moore SA, Ng R, Beltrán-Valero de Bernabe D, Faulkner JA, and Campbell KP. Genetic ablation of complement C3 attenuates muscle pathology in dysferlin-deficient mice. J 
Clin Invest. 120: 4366-4374. 2010. [Medline] [CrossRef]

46. Millay DP, Maillet M, Roche JA, Sargent MA, McNally EM, Bloch RJ, and Molkentin JD. Genetic manipulation of dysferlin expression in skeletal muscle: Novel insights into muscular dystrophy. Am J Pathol. 175: 1817-1823. 2009. [Medline] [CrossRef]

47. Ho M, Post CM, Donahue LR, Lidov HG, Bronson RT, Goolsby H, Watkins SC, Cox GA, and Brown RH Jr. Disruption of muscle membrane and phenotype divergence in two novel mouse models of dysferlin deficiency. Hum Mol Genet. 13: 1999-2010. 2004. [Medline] [CrossRef]

48. Kobayashi K, Izawa T, Kuwamura M, and Yamate J. The distribution and characterization of skeletal muscle lesions in dysferlin-deficient SJL and A/J mice. Exp Toxicol Pathol. 62: 509-517. 2010. [Medline] [CrossRef]

49. Kostek CA, Dominov JA, and Miller JB. Up-regulation of MHC class I expression accompanies but is not required for spontaneous myopathy in dysferlin-deficient SJL/J mice. Am J Pathol. 160: 833-839. 2002. [Medline] [CrossRef]

50. Fanin M, and Angelini C. Muscle pathology in dysferlin deficiency. Neuropathol Appl Neurobiol. 28: 461-470. 2002. [Medline] [CrossRef]

51. Dixon JE, Allan JE, Doherty PC, and Hume DA. Immunohistochemical analysis of the involvement of F4/80 and Iapositive macrophages in mouse liver infected with lymphocytic choriomeningitis virus. J Leukoc Biol. 40: 617-628. 1986. [Medline]

52. Sunderkötter C, Kunz M, Steinbrink K, Meinardus-Hager G, Goebeler M, Bildau H, and Sorg C. Resistance of mice to experimental leishmaniasis is associated with more rapid appearance of mature macrophages in vitro and in vivo. $\mathrm{J}$ Immunol. 151: 4891-4901. 1993. [Medline]

53. Fujita E, Kouroku Y, Isoai A, Kumagai H, Misutani A, Matsuda C, Hayashi YK, and Momoi T. Two endoplasmic reticulum-associated degradation (ERAD) systems for the novel variant of the mutant dysferlin: Ubiquitin/proteasome ERAD(I) and autophagy/lysosome ERAD(II). Hum Mol Genet. 16: 618-629. 2007. [Medline] [CrossRef]

54. Ikezoe K, Furuya H, Ohyagi Y, Osoegawa M, Nishino I, Nonaka I, and Kira J. Dysferlin expression in tubular aggregates: Their possible relationship to endoplasmic reticulum stress. Acta Neuropathol. 105: 603-609. 2003. [Medline]

55. Ikezoe K, Nakamori M, Furuya H, Arahata H, Kanemoto S, Kimura T, Imaizumi K, Takahashi MP, Sakoda S, Fujii N, and Kira J. Endoplasmic reticulum stress in myotonic dystrophy type 1 muscle. Acta Neuropathol. 114: 527-535. 2007. [Medline] [CrossRef]

56. Vattemi G, Engel WK, McFerrin J, and Askanas V. Endoplasmic reticulum stress and unfolded protein response in inclusion body myositis muscle. Am J Pathol. 164: 1-7. 2004. [Medline] [CrossRef]

57. Kobayashi K, Izawa T, Kuwamura M, and Yamate J. Comparative gene expression analysis in the skeletal muscles of dysferlin-deficient SJL/J and A/J mice. J Toxicol Pathol. 24: 49-62. 2011. [Medline] [CrossRef]

58. Langin $\mathrm{D}$. The role of uncoupling protein 2 in the development of type 2 diabetes. Drugs Today (Barc). 39: 287-295. 2003. [Medline] [CrossRef]

59. Bodyak N, Rigor DL, Chen YS, Han Y, Bisping E, Pu WT, and Kang PM. Uncoupling protein 2 modulates cell viability in adult rat cardiomyocytes. Am J Physiol Heart Circ Physiol. 293: H829-H835. 2007. [Medline] [CrossRef]
60. Roach WG, Chavez JA, Mîinea CP, and Lienhard GE. Substrate specificity and effect on GLUT4 translocation of the Rab GTPase-activating protein Tbcld1. Biochem J. 403: 353-358. 2007. [Medline] [CrossRef]

61. Chadt A, Leicht K, Deshmukh A, Jiang LQ, Scherneck S, Bernhardt U, Dreja T, Vogel H, Schmolz K, Kluge R, Zierath JR, Hultschig C, Hoeben RC, Schürmann A, Joost HG, and Al-Hasani H. Tbcldl mutation in lean mouse strain confers leanness and protects from diet-induced obesity. Nat Genet. 40: 1354-1359. 2008. [Medline] [CrossRef]

62. Islam T, McConnell R, Gauderman WJ, Avol E, Peters JM, and Gilliland FD. Ozone, oxidant defense genes, and risk of asthma during adolescence. Am J Respir Crit Care Med. 177: 388-395. 2008. [Medline] [CrossRef]

63. Jorquera G, Juretić N, Jaimovich E, and Riveros N. Membrane depolarization induces calcium-dependent upregulation of Hsp70 and Hmox-1 in skeletal muscle cells. Am J Physiol Cell Physiol. 297: C581-C590. 2009. [Medline] [CrossRef]

64. Silomon M, Bauer I, Bauer M, Nolting J, Paxian M, and Rensing H. Induction of heme oxygenase-1 and heat shock protein 70 in rat hepatocytes: The role of calcium signaling. Cell Mol Biol Lett. 12: 25-38. 2007. [Medline] [CrossRef]

65. O'Neill DE, and Noble EG. Constitutive expression of inducible Hsp70 is linked to natural shifts in skeletal muscle phenotype. Acta Physiol Scand. 181: 35-41. 2004. [Medline] [CrossRef]

66. Krajacic P, Hermanowski J, Lozynska O, Khurana TS, and Lamitina T. The C. elegans dysferlin homolog fer- 1 is expressed in muscle and fer- 1 mutations initiate altered gene expression of muscle enriched genes. Physiol Genomics. 40: 8-14. 2009. [Medline] [CrossRef]

67. Li ZH, Dulyaninova NG, House RP, Almo SC, and Bresnick AR. S100A4 regulates macrophage chemotaxis. Mol Biol Cell. 21: 2598-2610. 2010. [Medline] [CrossRef]

68. Wenzel K, Zabojszcza J, Carl M, Taubert S, Lass A, Harris CL, Ho M, Schulz H, Hummel O, Hubner N, Osterziel KJ, and Spuler S. Increased susceptibility to complement attack due to down-regulation of decay-accelerating factor/CD55 in dysferlin-deficient muscular dystrophy. J Immunol. 175: 6219-6225. 2005. [Medline]

69. Lynch DM, and Kay PH. Studies on the polymorphism of the fifth component of complement in laboratory mice. Exp Clin Immunogenet. 12: 253-260. 1995. [Medline]

70. Rhodes JC, Wicker LS, and Urba WJ. Genetic control of susceptibility to Cryptococcus neoformans in mice. Infect Immun. 29: 494-499. 1980. [Medline]

71. von der Hagen M, Laval SH, Cree LM, Haldane F, Pocock M, Wappler I, Peters H, Reitsamer HA, Hoger H, Wiedner M, Oberndorfer F, Anderson LV, Straub V, Bittner RE, and Bushby KM. The differential gene expression profiles of proximal and distal muscle groups are altered in pre-pathological dysferlin-deficient mice. Neuromuscul Disord. 15: 863-877. 2005. [Medline] [CrossRef]

72. Suzuki N, Aoki M, Hinuma Y, Takahashi T, Onodera Y, Ishigaki A, Kato M, Warita H, Tateyama M, and Itoyama Y. Expression profiling with progression of dystrophic change in dysferlin-deficient mice (SJL). Neurosci Res. 52: 47-60. 2005. [Medline] [CrossRef]

73. Bernard CC, and Carnegie PR. Experimental autoimmune encephalomyelitis in mice: Immunologic response to mouse spinal cord and myelin basic proteins. J Immunol. 
114: 1537-1540. 1975. [Medline]

74. Rosenberg NL, Ringel SP, and Kotzin BL. Experimental autoimmune myositis in SJL/J mice. Clin Exp Immunol. 68: 117-129. 1987. [Medline]

75. Tzou SC, Lupi I, Landek M, Gutenberg A, Tzou YM, Kimura H, Pinna G, Rose NR, and Caturegli P. Autoimmune hypophysitis of SJL mice: Clinical insights from a new animal model. Endocrinology. 149: 3461-3469. 2008. [Medline] [CrossRef]

76. Nagaraju K, Rawat R, Veszelovszky E, Thapliyal R, Kesari A, Sparks S, Raben N, Plotz P, and Hoffman EP. Dysferlin deficiency enhances monocyte phagocytosis: A model for the inflammatory onset of limb-girdle muscular dystrophy 2B. Am J Pathol. 172: 774-785. 2008. [Medline] [CrossRef]

77. Chiu YH, Hornsey MA, Klinge L, Jørgensen LH, Laval SH, Charlton R, Barresi R, Straub V, Lochmüller H, and Bushby K. Attenuated muscle regeneration is a key factor in dysferlin-deficient muscular dystrophy. Hum Mol Genet. 18: 1976-1989. 2009. [Medline] [CrossRef]

78. Nguyen K, Bassez G, Krahn M, Bernard R, Laforêt P, Labelle V, Urtizberea JA, Figarella-Branger D, Romero N, Attarian S, Leturcq F, Pouget J, Lévy N, and Eymard B. Phenotypic study in 40 patients with dysferlin gene mutations: High frequency of atypical phenotypes. Arch Neurol. 64: 1176-1182. 2007. [Medline] [CrossRef]

79. Grieger JC, and Samulski RJ. Packaging capacity of adenoassociated virus serotypes: Impact of larger genomes on infectivity and postentry steps. J Virol. 79: 9933-9944. 2005. [Medline] [CrossRef]

80. Yuasa K, Sakamoto M, Miyagoe-Suzuki Y, Tanouchi A, Yamamoto H, Li J, Chamberlain JS, Xiao X, and Takeda S. Adeno-associated virus vector-mediated gene transfer into dystrophin-deficient skeletal muscles evokes enhanced immune response against the transgene product. Gene Ther. 9: 1576-1588. 2002. [Medline] [CrossRef]

81. Mingozzi F, and High KA. Immune responses to AAV clinical trials. Curr Gene Ther. 7: 316-324. 2007. [Medline] [CrossRef]

82. Lostal W, Bartoli M, Bourg N, Roudaut C, Bentaïb A, Miyake K, Guerchet N, Fougerousse F, McNeil P, and Richard I. Efficient recovery of dysferlin deficiency by dual adenoassociated vector-mediated gene transfer. Hum Mol Genet. 19: 1897-1907. 2010. [Medline] [CrossRef]

83. Sancricca C, Mirabella M, Gliubizzi C, Broccolini A, Gi- daro T, and Morosetti R. Vessel-associated stem cells from skeletal muscle: From biology to future uses in cell therapy. World J Stem Cells. 2: 39-49. 2010. [Medline] [CrossRef]

84. Leriche-Guérin K, Anderson LV, Wrogemann K, Roy B, Goulet M, and Tremblay JP. Dysferlin expression after normal myoblast transplantation in SCID and in SJL mice. Neuromuscul Disord. 12: 167-173. 2002. [Medline] [CrossRef]

85. Kong KY, Ren J, Kraus M, Finklestein SP, and Brown RH Jr. Human umbilical cord blood cells differentiate into muscle in SJL muscular dystrophy mice. Stem Cells. 22: 981-993. 2004. [Medline] [CrossRef]

86. Wagner KR, Fleckenstein JL, Amato AA, Barohn RJ, Bushby K, Escolar DM, Flanigan KM, Pestronk A, Tawil R, Wolfe GI, Eagle M, Florence JM, King WM, Pandya S, Straub V, Juneau P, Meyers K, Csimma C, Araujo T, Allen R, Parsons SA, Wozney JM, Lavallie ER, and Mendell JR. A phase I/II trial of MYO-029 in adult subjects with muscular dystrophy. Ann Neurol. 63: 561-571. 2008. [Medline] [CrossRef]

87. Nemoto H, Konno S, Sugimoto H, Nakazora H, Nomoto N, Murata M, Kitazono H, and Fujioka T. Anti-TNF therapy using etanercept suppresses degenerative and inflammatory changes in skeletal muscle of older SJL/J mice. Exp Mol Pathol. 90: 264-270. 2011. [Medline] [CrossRef]

88. Han R. Muscle membrane repair and inflammatory attack in dysferlinopathy. Skelet Muscle. 1: 10. 2011. [Medline] [CrossRef]

89. Confalonieri P, Oliva L, Andreetta F, Lorenzoni R, Dassi P, Mariani E, Morandi L, Mora M, Comelio F, and Mantegazza R. Muscle inflammation and MHC class I up-regulation in muscular dystrophy with lack of dysferlin: An immunopathological study. J Neuroimmunol. 142: 130-136. 2003. [Medline] [CrossRef]

90. Prohászka Z, Singh M, Nagy K, Kiss E, Lakos G, Duba J, and Füst G. Heat shock protein 70 is a potent activator of the human complement system. Cell Stress Chaperones. 7: 17-22. 2002. [Medline] [CrossRef]

91. Grundtman C, Bruton J, Yamada T, Östberg T, Pisetsky DS, Harris HE, Andersson U, Lundberg IE, and Weserblad H. Effects of HMGB1 on in vitro responses of isolated muscle fibers and functional aspects in skeletal muscles of idiopathic inflammatory myopathies. FASB J. 24: 743-757. 2010. 